\title{
TAJEMNICZY BRAT JAKUB \\ - CZTERNASTOWIECZNY LEKTOR DOMINIKAŃSKI \\ (przyczynek do studiów nad średniowieczną sfragistyką i monastycyzmem)
}

\author{
A MYSTERIOUS BROTHER JAMES \\ - THE $14^{\text {TH }}$ CENTURY DOMINICAN LECTOR
}

(a contribution to studies of medieval sfragistics and monasticism)

\author{
Artur Dębski* \\ Iwona Marciniak \\ Instytut Prahistorii, Uniwersytet im. Adama Mickiewicza \\ Św. Marcin 78, 61-809 Poznań
}

\begin{abstract}
The article presents a thorough interpretation of a seal stamp, found during the archaeological excavations at the northern side of the Sacred Mary Church in the Poznan Cathedral Island (Ostrów Tumski). The stamp is dated to the period between the end of the $13^{\text {th }}$ and the first half of the $14^{\text {th }}$ century. This chronology is based upon its form and elements of its decoration. A legend inscribed on the stamp's frame, informing that its belonged to James - a lector of the preacher order, made possible to identify a social status of the owner along with his position in the Dominican structure. Unfortunately, neither connection between James and any concrete order nor whereabouts of his stay at Ostrów Tumski were recognized. These questions might be answered only after more detailed studies of the Dominican related archives are carried out.
\end{abstract}

Inspiracją dla niniejszego artykułu było odkrycie, jakiego dokonano podczas badań archeologicznych prowadzonych w 2003 r. na Ostrowie Tumskim w Poznaniu. Po północnej stronie kościoła pod wezwaniem Najświętszej Marii Panny (ryc.), na terenie posesji Ostrów Tumski 10, natrafiono na średniowieczny tłok pieczętny (tab. I : 1). Znalezisko ma charakterystyczny dla pieczęci kościelnych ostroowalny kształt wysokości $3,7 \mathrm{~cm}$ i szerokości $2,3 \mathrm{~cm}$. Odlane zostało w formie płaskiej sztabki ze stopu miedziopochodnego - prawdopodobnie z brązu. Wzdłuż jego osi, na górnej grzbietowej stronie, biegnie nieznacznie wystające żeberko zakończone w szczytowej partii niewielkim uszkiem, pozwalającym na przytroczenie przedmiotu do pasa bądź zawieszenie na szyi. Spodnia, użytkowa strona tłoka ma wyrytą negatywowo w metalu kompozycję, mająca

\footnotetext{
* Autor jest stypendystą Fundacji na Rzecz Nauki Polskiej.
} 


\section{$\times$}
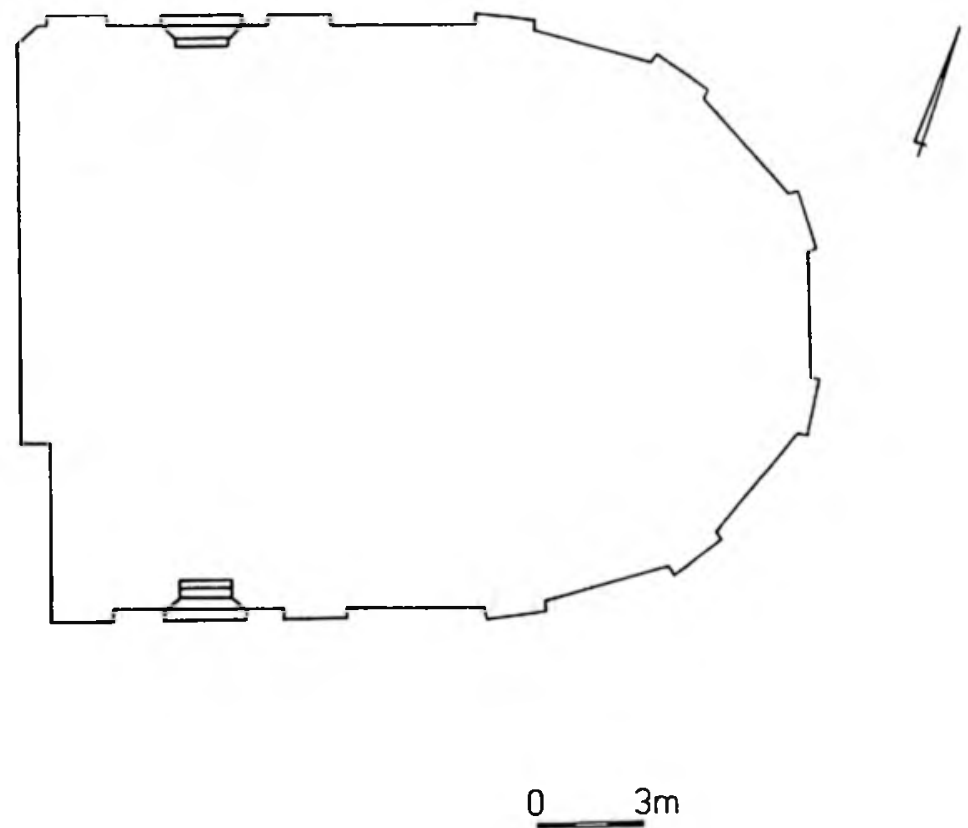

Ryc. 1. Poznań-Ostrów Tumski, stanowisko 9/10. Lokalizacja miejsca odkrycia tloka pieczętnego lektora Jakuba

Fig. 1. Poznań-Ostrów Tumski, site 9/10. Location of the seal stamp of the lector James

identyfikować właściciela pieczęci ${ }^{1}$. W polu wyobrażono dwie postacie (ryc. 2b). Pierwsza z nich przedstawia wysokiego mężczyznę z brodą i wąsami, ubranego w sięgającą kostek długą szatę, na którą jest narzucone nieco krótsze okrycie wierzchnie. W lewej dłoni trzyma on księgę, zaś w prawej - laskę zwieńczoną kulistą gałką. Przez prawe ramię ma przewieszoną torbę podróżną w taki sposób, że swobodnie spoczywa ona na jego lewym biodrze. Na wierzchu torby widnieje wyobrażenie muszli. Mężczyzna nosi na głowie kapelusz z szerokim rondem. Druga postać, z wygoloną na głowie tonsurą, przedstawiona została w adoracyjnej pozycji klęczącej. Złożone dłonie uniosła przed sobą na wysokość twarzy w geście modlitwy. Jej długa, luźno spływająca szata ma wyraźnie zaznaczony kaptur, teraz odrzucony na plecy. Klęczący unosi twarz wpatrując się w stojącego przed nim mężczyznę, którego postawa, a zwłaszcza ułożenie stóp (prawa stopa jest ukazana od wewnątrz, a lewa - z przodu) sugeruja, że zwraca się on właśnie ku modlącemu się

\footnotetext{
'Wiszewski 1998 , s. 12.
} 

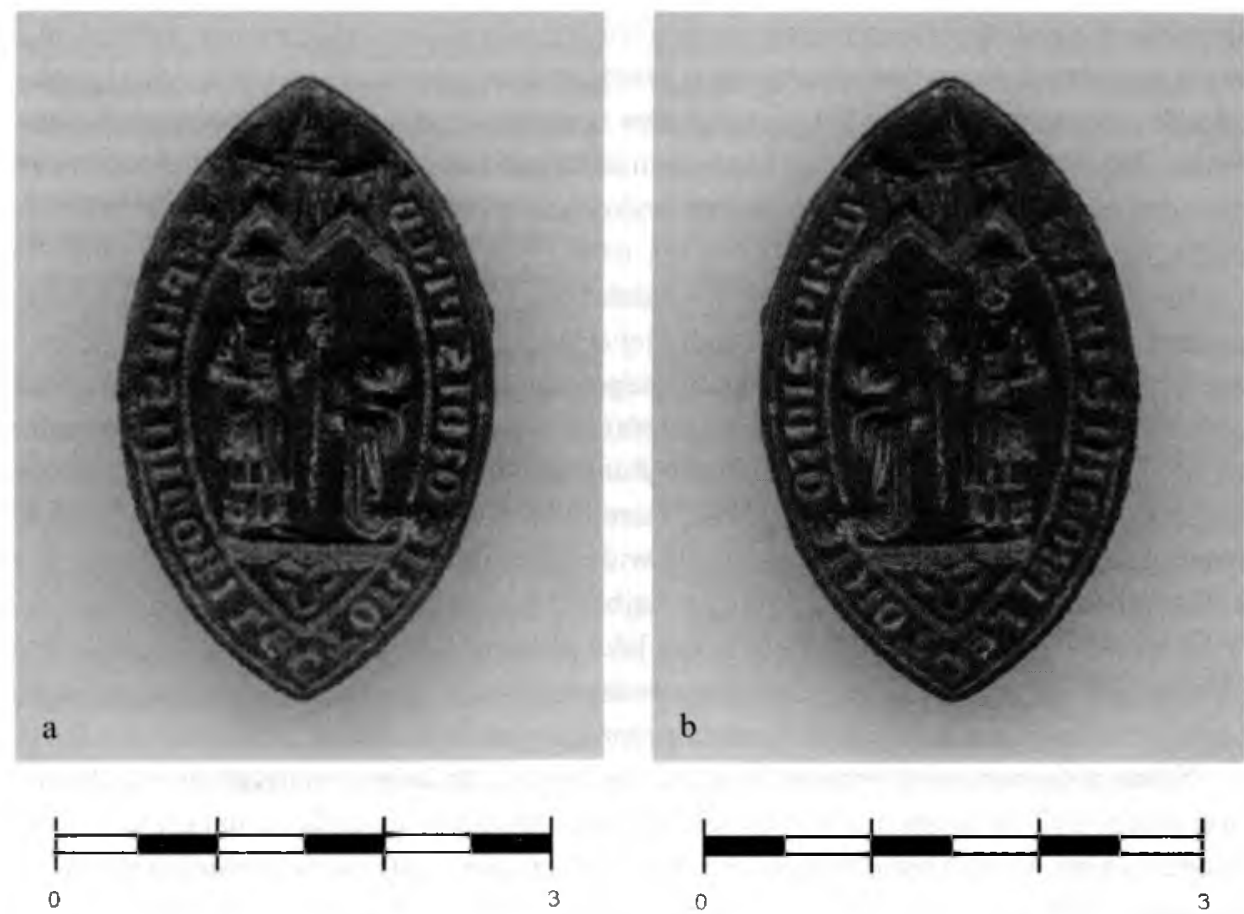

Ryc. 2. Poznań-Ostrów Tumski, stanowisko 9/10. Tłok pieczętny lektora Jakuba: a - spodnia strona zabytku przedmiotowy, b - pozytyw uzyskany w wyniku obróbki komputerowej

Fig. 2. Poznań-Ostrów Tumski, site 9/10. Seal stamp of the lector James: a - artifact, b - a computer-generated picture

zakonnikowi. Poniżej wyobrażono trójlistny motyw zdobniczy, wypełniający dolną część pola pieczęci. Z kolei w górnej części kompozycji widnieje trójskrzydłowy motyw architektoniczny, jak się wydaje, zaopatrzony w dodatkowe dwie wieże, których obecność sugerują ich ledwie zaznaczone zwieńczenia, wyobrażone po obu stronach środkowej wieży. W górnej partii tej ostatniej znajduje się trójlistna rozeta, odpowiadająca ściśle motywowi widniejącemu w dolnej części pola pieczęci. Przedstawioną budowlę zaopatrzono w wyraźnie zarysowane okna, o łukowato zakończonych szczytach. Kompozycję okolono napisem wykonanym średniowieczną kapitałą z elementami uncjały. Dość głęboko ryte litery pozwalają się odczytać jako: S:FRIS•IACOBI•LECTORIS: ORDIS•PRED'. Tłok zachowany jest w bardzo dobrym stanie. Niewielkie ubytki spowodowane korozją nie utrudniają identyfikacji poszczególnych elementów kompozycji. Dbałość o precyzyjne przedstawienie tak drobnych szczegółów, jak broda, muszla czy tonsura, wskazuje na wysokie kwalifikacje rzemieślnika, któremu zlecono wykonanie stempla. Poszczególne fałdy szat obu postaci wyobrażone zostaly na tyle szczegółowo, że widać nawet zmarszczenia rękawów w zagięciach unoszonych w górę rąk. Wydaje 
się, że przy produkcji tłoka zastosowano technikę odlewu na wosk tracony. Otrzymany w ten sposób wyrób poddano następnie ręcznej obróbce przy użyciu pilnika, rylca i punktaka. Pilnikiem usunięto nadlewy, zwłaszcza w rejonie uszka na grzbietowej stronie zabytku. Za pomocą rylca uzyskano zapewne niektóre szczegóły motywu architektonicznego oraz muszli. Wreszcie punktakiem wykonano perełkowanie obramienia legendy otokowej.

Już pobieżna analiza przedstawienia pozwala na identyfikację widniejących na tłoku postaci, co było przecież priorytetem dla jej właściciela. Klęcząca postać to na pewno mężczyzna - duchowny, adorujący stojącego przed nim świętego, być może swojego patrona. Zarówno tonsura, jak i habit $\mathrm{z}$ kapturem nie pozwalają mieć co do tego wątpliwości. Ów święty zaopatrzony został w atrybuty pozwalające uznać go za pielgrzyma. Sa to: laska podróżna, torba oraz kapelusz z szerokim rondem. Jednakże dopiero brodata twarz, księga, a przede wszystkim muszla widniejąca na torbie określają go jako św. Jakuba Większego - apostoła ${ }^{2}$, którego najbardziej znane sanktuarium znajduje się w hiszpańskiej Compostelli. Święty Jakub jako pielgrzym pojawia się w ikonografii dopiero w XIII w. ${ }^{3}$, wcześniej natomiast wyobrażano go jako brodatego mężczyznę z księga bądź przedstawiano scenę jego śmierci przez ścięcie.

Nasuwa się oczywiste pytanie: kim był duchowny, do którego należał ów zagubiony tłok pieczętny? Informacji o właścicielu stempla dostarcza legenda okalająca przedstawione na nim wyobrażenie dewocyjne. Widniejący tam napis, po rozwinięciu skrótów, informuje: SIGILLUM FRATRIS IACOBI LECTORIS ORDINIS PREDICATORUM - „pieczęć brata Jakuba lektora zakonu kaznodziejskiego”. Zakon kaznodziejski to miano nadane przez papieża Honoriusza III dominikanom. Na pieczęci ukazano zatem wizerunek dominikańskiego lektora Jakuba modlącego się do swego osobistego patrona Jakuba z Compostelli. Kiedy jednakże żył ów Jakub, jaki byl jego status, a wreszcie co robił na Ostrowie Tumskim w Poznaniu? Odpowiedzi na niektóre z tych pytań szukać należy w historii zakonu kaznodziejskiego.

Wiek XIII - oprócz wielu innych, nie spotykanych dotąd zjawisk - przyniósł doniosłe zmiany w strukturach Kościoła. Wśród nich najbardziej znaczący wydaje się gwałtowny rozwój zakonów mendykanckich, oferujących zupełnie nowe formy krzewienia wiary katolickiej. Poczesne miejsce zajmuje w tym gronie dzieło św. Dominika Guzmana - zakon kaznodziejski. Organizacja ta, zatwierdzona przez najwyższe władze Kościoła w $1216 \mathrm{r}^{4}$, u samych podstaw swego istnienia kładla nacisk na przygotowanie merytoryczne jej członków. Jednym z ich głównych zadań miało być zwalczanie potencjalnych herezji na gruncie dysputy teologicznej. Na taką właśnie formę działalności duszpasterskiej miało wpływ zetknięcie się św. Dominika z przedstawicielami rodzącego się wówczas na południu Francji ruchu albigensów. Rangę nowo powstałego zakonu podkreśla już sama jego nazwa - zakon kaznodziejski - wynikająca z nadanego

\footnotetext{
${ }^{2}$ Janicka-Krzywda 1993, s. 45, 46.

${ }^{3}$ Knapiński 1999 , s. 429

${ }^{4}$ Dabrowska 1988, s. 28.
} 
dominikanom prawa głoszenia Słowa Bożego, dotąd zarezerwowanego jedynie dla biskupów ${ }^{5}$. Zarówno cel, jak i stosowane do jego osiagnięcia metody uczyniły z tej organizacji zakon typowo miejski. Tam bowiem można było spodziewać się licznych wyznawców, tam istniała możliwość wystapienia ewentualnych ruchów heretyckich, tam wreszcie bracia mogli oczekiwać kolejnych powołań. Początkowo rekrutowano jedynie młodzież po ukończeniu osiemnastego roku życia i z wykształceniem średnim ${ }^{6}$, mającym jednak stanowić zaledwie wstęp do dalszych studiów. Konstytucja zredagowana przez Jordana z Saksonii - drugiego po św. Dominiku generała zakonu - zabraniała tworzenia nowego klasztoru bez szkoły teologicznej ${ }^{7}$. Każdy bowiem dominikanin nie wyłączając przeora - zobowiązany był do ciagłego podnoszenia swoich kwalifikacji poprzez uczęszczanie na zajęcia z teologii. Odbywały się one w specjalnie w tym celu funkcjonującej przy każdym domu zakonnym szkole tzw. konwentualnej. Zajęcia odbywały się pod kierunkiem jednego $\mathrm{z}$ braci, noszacego tytuł lektora. Jednakże rychło wyszło na jaw, że przyklasztorne szkoły teologiczne nie są w stanie poradzić sobie z lukami w wykształceniu kandydatów do zakonu. W związku z dynamicznym rozwojem organizacji - a przede wszystkim z powstawaniem coraz to nowych domów w mniejszych ośrodkach miejskich, oddalonych od wielkich centrów uniwersyteckich - okazało się, że nowi członkowie nie dysponują odpowiednimi podstawami do rozpoczęcia nauki na wyższym poziomie. Zaczęto wówczas tworzyć tzw. studia grammaticae. Ich zadaniem było uzupełnienie braków wykształcenia w zakresie znajomości łaciny oraz umiejętności czytania i pisania. Przeznaczano na nie nowicjat, a więc dwuletni okres, jaki każdy nowo przyjęty brat miał na zapoznanie się z życiem wspólnoty, ze śpiewem, liturgią oraz pozostałymi przepisami zakonnymi ${ }^{8}$. Jednakże $i$ to nie wystarczyło. W związu z samoistnie powstającymi szkołami uzupełniającymi braki wykształcenia w zakresie sztuk wyzwolonych, w 1259 r. wydano pozwolenie - a już w dwa lata później wręcz nakaz - na zakładanie studiów artium, zwanych inaczej studia logicae, w liczbie koniecznej do zaspokojenia potrzeb danej prowincji ${ }^{9}$. Oznaczało to, że studia te były szkołami międzyklasztornymi, obsługującymi jednocześnie kilka konwentów. Nauczycielem w studium logicae był lektor artium - często początkujący lektor teologii ${ }^{10}$. Podobny charakter miały tzw. szkoły partykularne. Były to szkoły teologiczne uzupełniające i wyrównujące poziom wykształcenia teologicznego ${ }^{11}$. Kształcono w nich młodzież zakonną, dając jej podstawową wiedzę z zakresu teologii, którą mieli oni następnie ugruntowywać i powtarzać w szkołach konwentualnych. Intencja ich powstania było utrzymanie jednolitego poziomu wykształcenia dla wszystkich członków zakonu, bez względu na miejsce położenia klasztoru. Tutaj, podobnie jak w szkołach konwentualnych, zajęcia prowadził

\footnotetext{
${ }^{5}$ Dąbrowska 1988 , s. 28.

${ }^{6} \mathrm{~K}$ i elar 1969 , s. 160.

${ }^{7} \mathrm{~K}$ i elar 1969 , s. 159.

${ }^{8} \mathrm{~K}$ i elar 1975 , s. 272.

${ }^{9} \mathrm{~K}$ ielar 1969 , s. 160.

${ }^{10} \mathrm{~K}$ ielar 1975 , s. 276.

${ }^{11}$ Kielar 1969, s. 161.
} 
lektor świętej teologii. Kolejną ze szkół dominikańskich były studia naturarum lub naturalium, kształcące w zakresie filozofii. Zaczęły one powstawać w drugiej połowie XIII w. w związku z recepcją arystotelizmu'2 ${ }^{\prime 2}$ Także i te szkoły, prowadzone przez lektorów teologii bądź posiadaczy uniwersyteckiego stopnia magistra artium, miały charakter międzyklasztorny. Ostatnią wreszcie kategorią studiów dominikańskich były tzw. studia generale $^{13}$. Tworzono je w ośrodkach uniwersyteckich $w$ celu kształcenia magistrów i lektorów, a więc przyszłych nauczycieli teologii. Jako jedyne miały one uprawnienia do przyjmowania studentów z innych prowincji zakonnych. Do prowadzenia studium generale konieczny był stopień magistra (profesora) teologii, a więc najwyższy stopień uniwersytecki, jaki można było osiągnąć. W hierarchii zatem szkolnictwa dominikańskiego lektor zajmował stanowisko najwyższe, ustępujące jedynie magistrowi teologii. W konwencie lektor był drugą osobą po przeorze klasztoru, często zdarzało się, że piastował obie te funkcje. Jego status społeczny był na tyle wysoki, że osoby z tym tytulem nierzadko występują na dokumentach książęcych jako świadkowie nadań gruntów czy wydawanych przywilejów ${ }^{14}$. O takiej właśnie wysokiej pozycji społecznej, jednoznacznie określonej przez legendę otokową możemy mówić w przypadku właściciela odkrytego tłoka poznańskiego.

Datowanie znaleziska nastręcza, niestety, znacznych trudności, zawodzą bowiem w tym przypadku metody archeologiczne. Tłok odkryty został na złożu wtórnym, na głębokości 1,04 m od powierzchni gruntu. Spoczywał w wypełnisku wkopu powstałego podczas badań prowadzonych w bezpośrednim sąsiedztwie kościoła w 1946 r. Pozostaje zatem datowanie na podstawie dostępnego materiału sfragistycznego $\mathrm{z}$ terenu Polski. Tłoki o kształcie zbliżonym do opisanego powyżej funkcjonują wedhug M. Haisiga w XIII - XIV w. ${ }^{15}$ Prawie identyczną z omawianym okazem formę ma egzemplarz pochodzący z klasztoru Klarysek wrocławskich, datowany na XIV w. (ryc. 2a) ${ }^{16}$. Analiza poszczególnych elementów wyobrażenia także pozwala na odszukanie analogicznych motywów ikonograficznych $w$ istniejącym materiale sfragistycznym. Niestety, nie można się w tym przypadku oprzeć na głównej części kompozycji zdobniczej, gdyż tego rodzaju przedstawienia dewocyjne pojawiają się przez całe średniowiecze i nie dają się ująć w jakieś ściślejsze ramy chronologiczne. Jednakże większość z nich różni się od omawianego okazu dość znacznie sposobem rozmieszczenia postaci biorących udział w scenie. Autorom niniejszego artykułu znanych jest zaledwie kilka pieczęci, na których modląca się postać wyobrażona została obok patrona, zamiast znajdować się poniżej i być od niej oddzielona wyraźną granica. Są to $\mathrm{m}$. in.: trzynastowieczna pieczęć ksieni cysterek trzebnickich ${ }^{17}$, także trzynastowieczna pieczęć księcia mazowieckiego Bolesława ${ }^{18}$ i pochodząca z pierwszej

\footnotetext{
${ }^{12}$ Kielar 1969, s. 161.

${ }^{13} \mathrm{~K}$ oc zowski 2002, s. 159.

${ }^{14}$ K orolec 1962

${ }^{15} \mathrm{H}$ a is ig 1960 , s. 128.

${ }^{16}$ W todarek 1995 , s. 145 , fot. 17

${ }^{17}$ Wiszewski 1998 , s. 15 , fot. 5.

${ }^{18} \mathrm{P}$ iekosiński 1936 , s. 9 , fig. 428
} 

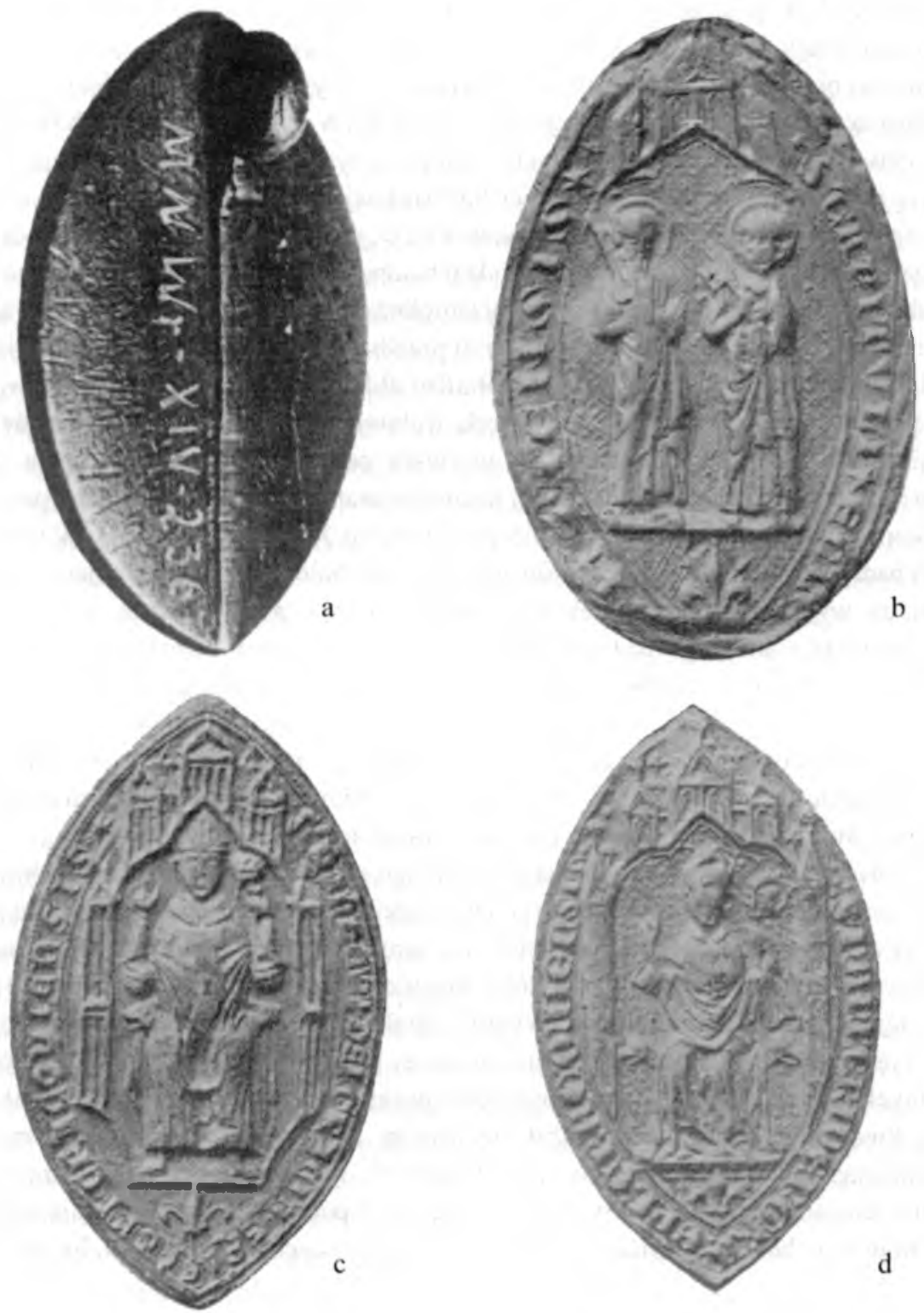

Ryc. 3. Tłoki pieczętne analogiczne do zabytku poznańskiego: a - klarysek wrocławskich (wg W łodare k 1995); b - kapituły benedyktynów tynieckich (wg P ie k os ińsk i 1899); c - krakowskiego biskupa Nankera z 1320 r. (wg Piekosiński 1899); d - krakowskiego biskupa Nankera z 1325 r. (wg Piekosiński 1899)

Fig. 3. Seal stamps analogical to the Poznań artifact: a - of the Wroclaw St.Clara convent (after W lodar e k 1995); b - of the Tyniec Benedictine (after P i ekosińsk i 1899); c - of the Kraków bishop Nanker from 1320 (after P i e kos ińsk i 1899); d - of the Kraków bishop Nanker from 1325 (after P i e k o s ińs ki 1899). 
połowy XIV w. pieczęć kapłana Jakuba ${ }^{19}$. Dzięki zachowanym na terenie Polski egzemplarzom można stwierdzić, że przedstawienia dewocyjne, na których adorujący i adorowani wyobrażeni zostali na jednym poziomie, bez wyraźnej granicy oddzielającej sferę niebiańską od ziemskiej, występują nie później niż w pierwszej połowie XIV w.

Pewną pomocą przy określeniu chronologii zabytku może służyć wieńczący kompozycję motyw architektoniczny. Mniej lub bardziej szczegółowe wyobrażenia budowli występują na pieczęciach przez całe średniowiecze, jednakże te pochodzące $z$ końca XIV w. mają zwykle kształt rozbudowany w rodzaj baldachimu lub ołtarza wspartego na kolumnach $^{20}$. Tymczasem na omawianym egzemplarzu ma on prostą trójskrzydłową formę. Ostatni znany autorom przykład tej wersji przedstawień architektonicznych pojawia się w latach siedemdziesiatych XIV w. ${ }^{21}$ Bardzo zbliżony do omawianego motyw, zaopatrzony w identyczny trójdzielny maswerk, widnieje na pieczęci kapituły Benedyktynów tynieckich (ryc. 2b), datowanej na pierwszą połowę XIV w. ${ }^{22}$ Budowla $w$ typie nawiązującym nieco do wyobrażonej na analizowanym tłoku występuje na pieczęciach biskupa Nankera, datowanych na pierwszą połowę XIV w. ${ }^{23}$ (ryc. $2 \mathrm{~cd}$ ). W tym jednak przypadku została ona już rozbudowana do formy baldachimu. Interesujący wydaje się fakt, że wyobrażeniom architektury towarzyszą tu - przedstawione w dolnej części kompozycji - motywy trójlistnej lilii. Na tłoku z Ostrowa Tumskiego wyryto w tym miejscu trójlucze - symbol Trójcy Świętej ${ }^{24}$. Identyczne trójłucze widnieje także na centralnej wieży budowli, wieńczącej kompozycję. Analogiczne wyobrażenia występują w dolnych partiach pól pieczęci księcia śląskiego - Henryka V. Są one datowane na ostatnie dziesięciolecie XIII w. ${ }^{25} \mathrm{~W}$ późniejszym materiale sfragistycznym trójłucze zastępuje lilia bądź inne motywy, jak na przykład tarcze herbowe.

Kolejnym elementem, na podstawie którego można próbować uściślić chronologię znaleziska jest legenda otokowa. Styl użytej czcionki pozwala na określenie go jako kapitałę z elementami uncjały, o cechach w pewnym stopniu archaicznych w stosunku do datowania elementów ikonografii tłoka. Poszczególne litery mają proporcje $1: 1$, a więc nawiązuja jeszcze do stylu romańskiego ${ }^{26}$. Brak czytelnych cech pisma gotyckiego, takich jak szeryfy, wydłużanie proporcji liter czy skłonność do ornamentowania poszczególnych ich części za pomocą różnego rodzaju zgrubień sugeruje, że tłok powstał w okresie, kiedy styl gotycki nie zdążył się jeszcze zadomowić w piśmie rytym. Nawet zakładając konserwatyzm pisma epigraficznego ${ }^{27}$, nie należy przesuwać górnej granicy datowania analizowanej inskrypcji bardziej, niż na połowę XIV w. W późniejszym okresie dominuje bowiem w piśmie epigraficznym styl o cechach gotyckich. Ewentualna ar-

\footnotetext{
${ }^{19} \mathrm{P}$ i ek os iński 1899, s. 234, fig. 279.

${ }^{20} \mathrm{P}$ i ek os iński 1936, s. 34-36, fig. 508, 512, 514.

${ }^{21} \mathrm{P}$ i ek os iński 1899 , s. 270 , fig. 330.

${ }^{22} \mathrm{P}$ i ek os iński 1899, s. 194, fig. 216; P i e ch 1995, s. 124, 125.

${ }^{23} \mathrm{P}$ i ekos iński 1899, s. 192, 199, fig. 212, 222.

${ }^{24}$ F oestner 1990 , s. 60.

${ }^{25} \mathrm{P}$ fotenhauer 1879 , Abt. A, s. 4, Taf. II, ryc. 11, 12.

${ }^{26}$ Trelińska 1991, s. 18.

${ }^{27} \mathrm{~W} \nmid$ odarek 1995, s. 144.
} 
chaizacja tegoż pisma, sugerowana niekiedy w literaturze ${ }^{28}$, wydaje się odnosić raczej do okresu po połowie wieku XV, kiedy rzeczywiście w piśmiennictwie następuje powrót do form prostszych, wywodzących się jeszcze z romańszczyzny. Cechą wybitnie nawiązującą do poprzedniej epoki jest fakt niezamknięcia jeszcze uncjalnych liter c, a zwłaszcza e, które w XIV w. bywaja już raczej zamknięte ${ }^{29}$. Legenda otokowa zawiera imię właściciela pieczęci, co jest zrozumiałe i popularne na pieczęciach świeckich, a niezbyt często spotykane w przypadku tłoków należących do przedstawicieli kleru zakonnego. Większość bowiem tych ostatnich zawiera informacje identyfikujące patrona klasztoru, a niekiedy także nazwę miejscowości, w której był on usytuowany. Znacznie częściej określano na pieczęci urząd sprawowany przez jej właściciela. Oczywiście czyniono tak w przypadku tloków należących do pojedynczych zakonników, na przykład przełożonych bądź innych osób pełniących w życiu klasztoru ważne funkcje. Jeszcze rzadziej spotyka się imię właściciela poprzedzone słowem frater, bez względu na określony następnie piastowany przezeń urząd. Tłokami, na których wyryto takie właśnie objaśnienie, posługiwal się - w trzydziestych latach XIV w. - opat tyniecki Michał II. Do naszych czasów zachowały się dwie odmiany jego pieczęci ${ }^{30}$. Na pierwszej widnieje napis S(IGILLUM) F[...]IS [M]IChAE[LIS] SEC(U)NDI TICIE ABB(AT)IS. Legenda drugiego okazu, częściowo uszkodzona, pozwala jednak odczytać napis: FRATR[......]SIS ABBATIS. Tego typu inskrypcje występują jednak również dużo później ${ }^{31}$. W analizowanym tekście wystapiła tylko jedna ligatura liter o i r w wyrazie ordinis. Znacznie bogaciej reprezentowane są skróty, od suspensji (pred=predicatorum), z jej najbardziej radykalną forma - sygla $(s=$ sigillum), po dwie kontrakcje (fris=fratris, ordis=ordinis). Zarówno ligatury, jak i skróty są w przypadku epigrafii spotykane bardzo często, co wynika $\mathrm{z}$ trudności $w$ kształtowaniu twardego materiału, oraz z braku miejsca ${ }^{32}$. Nie można zatem na tej podstawie podjąć próby datacji zabytku.

Omawiana inskrypcja jest dość nietypowa w stosunku do innych, znanych ze średniowiecznych pieczęci klasztornych. Po pierwsze - zawiera nazwę zakonu: ordo predicatorum, po drugie - nie określono w niej ani miejsca położenia klasztoru, ani też jego wezwania, po trzecie - wyobrażono na niej osobistego patrona właściciela, zamiast patrona konwentu, wreszcie jest ona pieczęcią należącą do lektora. Zdaniem H. Krahmer, określenie nazwy zakonu determinowane było przynależnością do dominikanów, klarysek bądź bożogrobców ${ }^{33}$. Pogląd ten jednak podważony został w późniejszej literaturze ${ }^{\$ 4}$. Fakt nieokreślenia w legendzie macierzystego konwentu właściciela thumaczyć należy zajmowanym przez niego stanowiskiem. Dominikanie byli zakonem nadzwyczaj ruchliwym. Ich misja wymagała ciągłego przemieszczania się

\footnotetext{
${ }^{28}$ W łodarek 1995, s. 144.

${ }^{29}$ Trelińska 1991, s. 18, 31-32.

${ }^{30} \mathrm{Piech} 1995$, s. 130-132.

${ }^{31}$ Wój c ik 1998, s. 34, fot. 1.

${ }^{32}$ Semkowicz 2002, s. 402.

${ }^{33} \mathrm{~K}$ rahmer 1935 , s. $33-39$.

${ }^{34} \mathrm{~W}$ iszewski 1998 , s. 26,27
} 
w obrębie prowincji, w tym przypadku - zapewne polskiej. Wśród nich niewatpliwie najbardziej ruchliwi byli lektorzy, każdorazowo kierowani na nową placówkę przez kapitułę prowincjonalną ${ }^{35}$. W jednym konwencie spędzali oni krótki, najwyżej kilkuletni okres, a następnie przerzucano ich na inne miejsce. Oczywiście niekiedy stosowano odstępstwa od tej reguły, mianując wykładowcę teologii kilkakrotnie na tę samą placówkę, jednak przy takim systemie nominacji nie bylo sensu określać miejsca, w którym akurat dany lektor przebywał. Łatwiej było umieścić po prostu w legendzie pieczęci imię właściciela, który tytuł swój - wszak naukowy - nosił dożywotnio, pozostając lektorem bez względu na miejsce, w którym akurat przebywał. $Z$ tego samego powodu zrezygnowano $\mathrm{z}$ wyobrażenia $\mathrm{w}$ polu pieczęci patrona konwentu. W omawianym przypadku mamy zatem do czynienia z pieczęcią właściwie osobistą, bardziej związaną z właścicielem niż z instytucją, do której należał. W pochodzącym $\mathrm{z}$ terenu Polski klasztornym materiale sfragistycznym autorzy natrafili tylko na jeden przypadek, kiedy wlaściciel tłoka był tak związany ze swym osobistym patronem, że pieczętował swoje dokumenty jego wizerunkiem. Tłok ten należał do Jakuba Zbyluta - podprzeora zakonu dominikanów wroclawskich ${ }^{3 i}$. W polu pieczęci wyobrażono scenę ścięcia św. Jakuba, pod którą modli się jej właściciel. Legendę otokową zabytku odczytać można jako: +S.FRIS•IACOBI•ZBILUTI.ORD'PDIC - „pieczęć brata Jakuba Zbyluta zakon(u) dominikanów". Dokument, do którego przywieszono pieczęć pochodzi z $1290 \mathrm{r}$. Wydaje się zastanawiający fakt, że obydwa egzemplarze z bardzo osobistym - jak na należące do zakonnika - wyobrażeniem dewocyjnym dotyczą osób pochodzących $\mathrm{z}$ tego samego zakonu i w dodatku o tym samym imieniu. W przypadku lektora na uzasadnienie zastapienia patrona konwentu osobistym patronem właściciela pozwala ruchliwość tego ostatniego. Konieczność częstych zmian miejsca pobytu wymagalaby częstego zmieniania - kosztownych przecież - pieczęci. Trudno jednak w ten sposób motywować fakt pojawienia się osobistego patrona na pieczęci podprzeora; funkcja ta przypisana była przecież do konkretnego konwentu. Brak, niestety, szerszych podstaw do powiązania obu mnichów Jakubów: podprzeora i lektora w jedną osobę. Co prawda odkryty w Poznaniu tłok pieczętny wykazuje pewne cechy archaiczne, mogące postarzyć nieco jego datowanie. Sa to cechy liternictwa: otwarte jeszcze e i c czy ów trójliść, występujący jedynie na pieczęciach jednego z książąt śląskich z ostatniego dziesięciolecia XIII w. Ponadto charakter głównej sceny wyobrażenia oraz jej uzupełnienia w postaci architektury, nie wykluczają możliwości przesunięcia datacji znaleziska na koniec XIII w. Jednakże gdybyśmy przyjęli hipotezę, że wrocławski podprzeor po ukończeniu studium generale otrzymał tytuł lektora, a następnie zmienił pieczęć, trudno byłoby znaleźć wytłumaczenie faktu, że na nowym tłoku kazał wyryć tylko imię Jakub, zamiast Jakub Zbylut. Niestety, na obecnym etapie badań można jedynie zwrócić uwagę na podobieństwo obydwu okazów i poczekać na dalsze źródła, których dostarczyć może kwerenda archiwaliów dominikańskich.

\footnotetext{
${ }^{35}$ Kłoczowski 1969 , s. $112,113$.

${ }^{36} \mathrm{P}$ fotenhauer 1879 , s. 20 , Taf. IX, ryc. 81.
} 
Niewiele można powiedzieć na temat okoliczności, w jakich doszło do zagubienia thoka. Został on odkryty na terenie stanowiącej własność kapituły katedralnej zamkniętej posesji, sąsiadującej od północy z kościołem kolegiackim pod wezwaniem Najświętszej Marii Panny. Dostęp do tego miejsca utrudniony był także w średniowieczu, przynajmniej od XV w., o czym świadczy znikoma - w porównaniu z południowym otoczeniem światyni - liczba znajdowanych podczas prac wykopaliskowych monet $\mathrm{z}$ tego okresu. Niestety, sam kościół pochodzi z wieku XV, nie możemy zatem powiedzieć nic pewnego o sposobie zagospodarowania tego terenu $\mathrm{w}$ stuleciu poprzedzającym budowę kolegiaty. Na podstawie dotychczasowych badań możemy jedynie przyjąć, że w okresie pomiędzy wiekiem X a XV funkcjonowala na tym terenie pierwotna kaplica książęca, fundowana jeszcze przez żonę Mieszka - Dobrawę, zapewne przebudowana w stylu romańskim. Co w jej pobliżu mógł robić lektor Jakub? W interesującym nas okresie funkcjonuje już na drugim brzegu Warty klasztor dominikański. Jakub mógł zatem przybyć na poznański Ostrów w celu wygłoszenia kazania w tutejszej świątyni. Ponadto w bezpośrednim sąsiedztwie kościoła NMP zarejestrowano dowody na funkcjonowanie w tym miejscu, wzmiankowanej w źródłach, szkoły katedralnej ${ }^{37}$. Są to przede wszystkim wykonane $\mathrm{z}$ różnych materiałów stilusy ${ }^{38}$. Być może zatem nasz lektor zgubił swój tłok pieczętny składając wizytę miejscowym wykładowcom. Niestety, tej kwestii zapewne nie uda się już dziś rozstrzygnaćc.

Podsumowując można stwierdzić, że mnich Jakub - lektor zakonu dominikanów przybył na poznański Ostrów Tumski w końcu XIII lub w pierwszej połowie XIV w. i zapewne wtedy zagubił omówiony powyżej stempel. Czy przebywał on w gościnie u swych braci na lewym brzegu Warty, czy też był ich stalym nauczycielem, tego nie da się na obecnym etapie badań stwierdzić. Podobnie niemożliwe jest na razie uzyskanie odpowiedzi na pytanie o związki lączące lektora Jakuba z wrocławskim podprzeorem Jakubem Zbylutem. Odkryty w pobliżu kościoła NMP tłok pieczętny jest jedynym obecnie znanym źródłem potwierdzającym fakt posiadania przez lektorów dominikańskich osobistych pieczęci, dotąd bowiem nie natrafiono w archiwach na ślady dokumentów przez nich wystawianych. Już sam ten fakt decyduje o randze znaleziska. Ponadto styl wykonania pieczęci oraz cechy artystyczne wyobrażenia stawiają omówiony egzemplarz wśród najwyższej klasy miniaturowych dzieł sztuki rytowniczej średniowiecza. Nieznany artysta postaral się o nadanie postaciom cech indywidualnych. Kunszt rzemieślnika najpełniej obrazuje, sprawiający wrażenie ruchu, wizerunek św. Jakuba. Wzniesiona w górę laska oraz ułożenie stóp w ten sposób, że prawa ukazana jest od wewnątrz, a lewa z przodu, sugerują że zwraca się on właśnie ku adorującemu go mnichowi. Jeśli wziąć pod uwagę fakt, że obie postacie zostały wyobrażone z najdrobniejszymi szczegółami, wydaje się uzasadnione stwierdzenie, że omówiony tłok musiał być dość kosztownym nabytkiem, nawet dla osobistości tak znanej i szanowanej w konwencie jak lektor. Zdając sobie sprawę z ogromnej kulturotwórczej roli dominikanów należy stwierdzić, że lektorzy

\footnotetext{
${ }^{37}$ Nowacki 1964, s. $672-678$.

${ }^{38} \mathrm{~K}$ ócka-Krenz 2001, s. 10.
} 
stanowili absolutną elitę intelektualna, nie tylko w obrębie zakonu, ale także poza nim. Studia zagraniczne, które ukończyć musiał także i Jakub ${ }^{39}$, stawiały ich absolwentów w gronie najlepiej wyedukowanych mieszkańców średniowiecznej Europy. Wyższym wykształ- ceniem mogło pochwalić się tylko szczupłe grono magistrów, wśród których należy wymienić osobistości tej miary, co Tomasz z Akwinu czy Albert Wielki.

Same znaleziska średniowiecznych tłoków pieczętnych, które zostały zagubione, a nie celowo złożone (np. w grobie), należą podczas badań archeologicznych do rzadkości. Autorom znany jest tylko jeden taki przypadek z Tyńca, gdzie podczas prac wykopaliskowych natrafiono na złożu wtómym na trzynastowieczny tłok pieczętny konwentu benedyktynów. Stemple osobiste były - poza nielicznymi wyjątkami - skrzętnie niszczone po śmierci właściciela. W niektórych przypadkach zagubienie pieczęci wiązało się $\mathrm{z}$ dotkliwą kara, o czym przekonał się burmistrz Pragi, ścięty przed własnym domem za takie właśnie przestępstwo ${ }^{40}$. Trudno powiedzieć, czy lektora Jakuba spotkały z tego powodu jakieś konsekwencje. Jeśli tak było, to miały one zapewne charakter finansowy.

W rozstrzygnięciu problemu pochodzenia właściciela omawianego tłoka pomóc mogłaby szersza kwerenda archiwaliów. Być może pozwoliłaby ona uzyskać odpowiedź na pytanie w jakim celu Jakub przybył do Poznania? Czy był on miejscowym lektorem, czy tylko sprowadziła go tutaj jakaś określona sprawa? Czy wreszcie, opierając się na źródłach pisanych możliwe byłoby uściślenie przyjętego datowania zabytku? Kwestie te pozostają nadal otwarte. Kończąc powyższe rozważania należy podkreślić, że potencjał informacji tkwiących w odkrytym w Poznaniu tłoku pieczętnym nie został w żadnym razie wyczerpany, a artykuł niniejszy jest zaledwie wprowadzeniem do dalszych badań.

\section{BIBLIOGRAFIA}

Bobowski K.

1989 Dawne pieczęcie na Pomorzu Zachodnim, Szczecin.

Dábrowska A.

1988 Zakony w Polsce, (w:) Zakony w Polsce, cz. 2, Lódź, s. 27-67.

Foestner D.

1990 Świat symboliki chrześcijańskiej, Warszawa.

Janicka-Krzywda U.

1993 Patron - atrybut - symbol, Poznan.

Kielar P.

1969 Organizacja szkolnictwa dominikańskiego w Polsce w XIV wieku, „Studia Philosophiae Christianae" t. 5 , nr 1, s. $159-169$.

1975 Studia nad kulturq szkolnq $i$ intelektualnq dominikanów prowincji polskiej $w$ średniowieczu [Rés.: Liste des écrivains dominicains du couvent de Wroclaw], (w:) Studia nad historiq dominikanów w Polsce 1222-1972, t. I, Warszawa, s. 271-515.

\footnotetext{
${ }^{39} \mathrm{~W}$ pierwszej połowie XIV w. nie istniało jeszcze w Polsce studium kształcące lektorów (K o r o le c 2002).

${ }^{40}$ B obowski 1989 , s. 54.
} 
Kłoczowski J.

1969 Ksztalcenie w polskiej prowincji dominikańskiej w poczqtkach XVI w. [Zus.: Die Ausbildung der Mönche in der polnischen Provinz des Dominikanerordens in den Anfängen des 16. Jahrhunderts], „Zapiski Historyczne”, t. 34, z. 3, s. 107-123.

2002 Dominikanie w środkowo-wschodniej Europie i ich kultura intelektualna oraz pastoralna w wiekach średnich [Rés.: Les dominicains en Europe Central et de l'Est et leur culture intellectuelle et pastorale au Moyen Âge], (w:) Dominikanie w środkowej Europie w XIII-XV wieku. Studia nad historiq dominikanów w Polsce, t. 3, Poznań, s. 153-172.

Knapiński $R$.

1999 Titulus ecclesiae. Ikonografia, Warszawa.

Kócka-Krenz H.

2001 Archeologiczne świadectwa o poczqtkach szkolnictwa w Poznaniu, „Kronika Miasta Poznania” t. 4, s. 7-14.

Korolec J. B.

1962 Lista lektorów dominikańskich prowincji polskiej w XIII-XIV wieku, Materiały Zakładu Historii Filozofii Starożytnej i Średniowiecznej, t. 2, s. 196-213.

2002 Studium generale dominikanów klasztoru Świętej Trójcy w Krakowie, (w:) Dominikanie w środkowej Europie w XIII-XV wieku. Studia nad historiq dominikanów w Polsce, t. 3, Poznań, s. 173 $-187$.

Krahmer H.

1935 Beiträge zur Geschichte des geistlichen Siegels in Schlesien bis zum Jahre 1319, „Zeitschrift des Vereins für Geschichte Schlesiens" Bd. 69, s. 33-39.

Nowacki J.

1964 Dzieje archidiecezji poznańskiej, t. II: Archidiecezja poznańska w granicach historycznych i jej ustrój, Poznań.

Pfotenhauer P.

1879 Die schlesischen Siegel von 1250 bis 1300, beziehentlich 1327, Breslau.

Piech Z.

1995 Sredniowieczne pieczęcie țnieckie, (w:) Benedyktyni tynieccy w średniowieczu, Kraków, s. 121 -140 .

Piekosiński F.

1899 Pieczęcie polskie wieków średnich doby piastowskiej, Kraków.

1936 Pieczęcie polskie wieków średnich doby piastowskiej (Uzupelnienie), odbitka z „Wiadomości Numizmatyczno-Archeologicznych", t. XVI, s. 71-86; t. XVII, s. 55-78.

Semkowicz W.

2002 Paleografia lacinska, Kraków.

Trelińska B.

1991 Gotyckie pismo epigraficzne w Polsce, Lublin.

Wiszewski P.

1998 Średniowieczna ślaska pieczęć klasztorna jako środek przekazu informacji (XIII - 1 potowa $X V I w$.) [Sum.: The medieval silesian cloiser seal as a mean to transmitting information $\left(13^{\text {th }}-1^{\text {st }}\right.$ half of the $16^{\text {th }}$ c.)], (w:) Pieczęć w Polsce średniowiecznej i nowożytnej, Lublin, s. 11-29.

Wlodarek A.

1995 Trzynastowieczny tyniecki tlok pieczętny, (w:) Benedyktyni tỵnieccy w średniowieczu, Kraków, s. $141-145$.

Wójcik M. L.

1998 Pieczęcie cystersów jemielnickich do polowy XVI wieku (z zespolu Rep. 85 Archiwum Państwowego we Wroclawiu) [Sum.: The seals of cistercian monks from Jemielnica to the Ist half of the $16^{\text {th }}$ century (from the State Archives in Wrocław, Rep. 85)], Lublin. 


\section{A MYSTERIOUS BROTHER JAMES - THE $14^{\text {TH }}$ CENTURY DOMINICAN LECTOR}

(a contribution to studies of Medieval sfragistics and monasticism)

\section{Summary}

The article was prepared as a result of a seal piston discovery during the 2003 excavations at the Sacred Mary Church at Ostrów Tumski (site 9/10) in Poznań. It was found in a secondary deposit. This copper alloy artifact is decorated by a figure of kneeing monk in front of the standing figure of St. James of Compostella. The saint is represented with all pilgrim's attributes, namely bag, hat, and stick along with iconographic attributes of the James apostle such as beard, book and a shell attached to the bag. A triple-wing architectural motif was depicted above these two figures while a triple-arch - the Holy Trinity symbol - was placed below. Analysis of available sfragistic materials from Poland led to identification of formal analogies to subsequent compositional elements. Similar architectural motives to those from the Ostrów Tumski stamp have been registered on the Tyniec Benedictine seal dated to the second half of the $14^{\text {th }}$ century. Similar, albeit more elaborated, are also motives identified on the seals of Nanker, the Kraków bishop, dated to the same period. The only analogies to a triple-arch motif come from seals of the Silesian prince Henry $V$ and are dated to the last decade of the $13^{\text {th }}$ century. The frame seal legend refers directly to the $13^{\text {th }}$ century. It is indicated by a Romanesque proportion of letters, a lack of Gothic elements and unclosed uncial $\mathrm{e}$ and $\mathrm{c}$. Based upon these observations, one can argue that the seal was manufactured at the end of the $13^{\text {th }}$ or in the first half of the $14^{\text {th }}$ century.

An inscription at the stamp's frame makes possible to identify its owner. It was the brother James - a lector of the preacher order. This function was given to the Dominicans by pope Honorius III in 1216. It is argued that a figure on the seal is probably James himself, adoring St. James of Compostella, his personal patron. There is only one known case in the Polish monastery sfragistics, where a 'private' patron of the owner is depicted on a seal stamp. It belonged to Jakub Zbylut - a prior of the Wroclaw Dominicans - and it is dated to the last decade of the $13^{\text {th }}$ century. Unfortunately, there is no basis to merge these two individuals into one. A form of both seals is indicative of individualistic representation at some Dominicans seals, which is unusual in Polish sfragistics.

Dominican lectors graduated from foreign universities and belonged to an absolute intellectual elite in the Middle Ages. Their level of education was only slightly lower than holders of the university diplomas among those individuals like St. Thomas Aquinas or Albert the Great. A title of lector is indicative of a position of the theology teacher and lecturers of other subjects, which were taught in the Dominicans schools at that time. Thus, one could argue that the owner of the analyzed seal was a high rank individual in a local convent, its position being only slightly inferior than its prior. It is speculated that a principle of the Dominican convent, assuming turnover of its teaching staff within a given church province, is indirectly responsible for a lack of the convent patron portrayal on the seal, which was always the case when such an object belonged to its prior. The lectors have been assigned to a given monastery by the province chapter and then they have been constantly transferred from one place to the other. The Ostrów Tumski discovery is the only proof to date that the Dominican lectors got their own seals.

Unfortunately, there is no indications whether James was a lector of the Poznan monastery or was present there as a guest. Circumstances in which the seal piston was lost are also unknown. It is believed that more detailed studies of the Dominican related archives might shed some light onto these issues, including the lector James himself. 